$$
\begin{array}{l|l|l}
\text { Jurnal Eksplorasi Akuntansi } & \text { ISSN : 2656-3649 (Online) } \\
\text { Vol. 2, No. 2, Seri B, Mei 2020, Hal 2711- 2725 } & \text { http://jea.ppj.unp.ac.id/index.php/jea/issue/view/23 }
\end{array}
$$

\title{
PENGARUH KOMPENSASI EKSEKUTIF DAN EFISIENSI OPERASIONAL TERHADAP KINERJA KEUANGAN PERBANKAN YANG TERDAFTAR DI BURSA EFEK INDONESIA TAHUN 2016-2018
}

\author{
Thesa Aulia ${ }^{1}$, Erinos NR ${ }^{2}$ \\ ${ }^{1}$ Alumni Jurusan Akuntansi Fakultas Ekonomi Universitas Negeri Padang \\ ${ }^{2}$ Jurusan Akuntansi Fakultas Ekonomi Universitas Negeri Padang \\ *Korespondensi: thesaaulia.ta@gmail.com
}

\begin{abstract}
This study explain the effect of executive compensation and operational efficiency on the financial performance of banking company, which still unclear the effect of these variables. This study purposed to show and examine empirically the effect of executive compensation (XI), Non performing loan (X2), and Loan to deposit ration (X3) on financial performance banking company which measured by Return on asset $(Y)$. the method that used in this study was causative comperative. The data which are used in this study were obtained from the banking company that listed in BEI in 2016-2018 and the sample were collected based on purposive sampling and resulted 117 companies. The result of this study showed that executive compensation has effect on ROA, while non performing loan has negative effect and significant on ROA, and Loan to deposit ratio has positive effect and significant on ROA. The next study expected to use another variables in order to get a better result and describe the variables which has effect on financial performance in company.
\end{abstract}

Keywords : Executive Compensation, Financial Performance, Loan to Deposit Ration, Non Perfoming Loan, Return on Asset.

NR. Erinos \& Aulia, Thesa. (2020). Pengaruh Kompensasi Eksekutif Dan Efisiensi Operasional Terhadap Kinerja Keuangan Perbankan Yang Terdaftar di Bursa Efek Indonesia Tahun 2016-2018. Jurnal Eksplorasi Akuntansi. 2(2), Seri B, 2711-2725.

\section{PENDAHULUAN}

Sistem ekonomi negara terkait erat dengan keberadaan sektor perbankan. Lembaga perbankan adalah lembaga keuangan yang bertindak sebagai perantara antara pihak yang kelebihan dana dan pihak yang membutuhkan uang. Perbankan sebagai perantara berfungsi ketika kedua belah pihak percaya pada bank (Puspitasai, 2015). Bank perlu meningkatkan kinerja perusahaan dan tetap sehat untuk mempertahankan tingkat kepercayaan pelanggan. Kinerja manajemen digunakan sebagai ukuran kinerja perusahaan. Mencapai hasil bisnis di lembaga perbankan dapat ditunjukkan dengan bagaimana manajemen meningkatkan kinerja keuangan dan memprediksi risiko bisnis (Khassana, 2015). 
Bank menghadapi berbagai jenis risiko. Darmawati (2015) menemukan beberapa risiko yang sering dihadapi bank, termasuk 1) risiko kredit, 2) risiko likuiditas, dan 3) risiko operasional. Kinerja keuangan bank dipantau oleh bagaimana mengukur kemampuannya untuk mendapatkan ROA (laba atau laba). Return on assets (ROA) adalah rasio yang dapat digunakan untuk mengukur kemampuan perusahaan untuk menghasilkan pengembalian dari kegiatan investasi (Adawiya, 2017). Penelitian Dendawijaya (2003) menemukan bahwa ROA berfokus pada kemampuan perusahaan untuk menghasilkan laba dalam semua kegiatan bisnisnya. Pengembalian aset dipilih untuk mengukur kinerja keuangan bank. Beberapa alasan, termasuk pengembalian aset, adalah kemampuan untuk mengukur kemampuan bank untuk mengelola asetnya secara keseluruhan (Puspitasari, 2015).

Return on equity juga digunakan untuk mengukur efisiensi dan efektifitas meningkatkan aset untuk menghasilkan pembiayaan. Karena rasio ini adalah rasio laba setelah pajak terhadap total aset, semakin tinggi pengembalian investasi menunjukkan pengembalian yang lebih tinggi dan dengan demikian kinerja yang lebih baik. Efek bersihnya adalah pemegang saham dapat menikmati profitabilitas, karena peningkatan laba atas ekuitas menunjukkan peningkatan profitabilitas perusahaan (Barus dan Sulistyo, 2011). Salah satu faktor yang dapat menambah atau mengurangi laba atas aset (ROA) adalah pemberian kompensasi eksekutif. Upah eksekutif adalah upah yang terdiri dari uang tunai dan upah non tunai yang diterima oleh pejabat perusahaan di posisi perusahaan (Widjayanti, 2017). Sektor perbankan, yang memberikan penghargaan yang sangat kompetitif kepada para eksekutif, diharapkan untuk mencapai produktivitas, laba, dan bisnis yang akan terus tumbuh secara signifikan berdasarkan angkaangka keuangan yang dipublikasikan (Surrey dan Harto, 2014).

Penghargaan kompensasi (kompensasi) diatur oleh Bank Indonesia dengan Komite Kompensasi dan Nominasi. Namun, pembayaran bonus (bonus) kepada manajer bank tergantung pada Undang-Undang Perseroan Terbatas tahun 2007. Undang-undang ditentukan oleh RUPS, Forum Pemegang Saham Terbaik (Puspitasari, 2015). Sebuah survei (Kirin, 2013) menemukan bahwa hadiah itu adalah hadiah atau hadiah keuangan dan hukuman yang diberikan kepada CEO selama CEO itu bekerja. Ada tiga masalah terkait kompensasi. 1) bentuk kompensasi (kombinasi kompensasi), 2) jumlah kompensasi (tingkat kompensasi), 3) dan pengungkapan (pengungkapan). Menawarkan hadiah berdasarkan pencapaian kinerja departemen dengan keahlian khusus mereka. Kondisi ini tidak selalu linear, karena mereka berbeda dari situasi nyata bank-bank Indonesia (Muharram, 2004).

Sebuah studi oleh Brach dan M. Stulz (2010) menemukan bahwa kompensasi eksekutif tidak terkait dengan kinerja. Tidak ada bukti bahwa kompensasi eksekutif yang lebih tinggi meningkatkan kinerja. Studi ini didukung oleh Sheikh dan Karim (2015), di mana mereka menemukan bahwa tidak ada hubungan antara kompensasi eksekutif dan kinerja bank yang diamanatkan agensi. Berbeda dengan penelitian oleh Parimana dan Wisadha (2015), kami menemukan bahwa kompensasi eksekutif memiliki dampak yang signifikan dan positif terhadap kinerja keuangan. Faktor kedua yang dapat mempengaruhi pengembalian atas aset (ROA) adalah efisiensi operasional. Efisiensi adalah perbandingan input dan output terbaik antara laba dan sumber daya terbatas (Marbon, 2010). Efisiensi bisnis adalah metrik yang digunakan untuk mengukur jumlah kemampuan perusahaan untuk melakukan bisnis. Geel et al. (2014) mengungkapkan penggunaan rasio keuangan untuk mengukur efisiensi operasional keuangan. Maria (2015) dapat menggunakan 1) NPL untuk mengukur efisiensi operasional bank. Kredit macet adalah rasio kredit macet terhadap total pinjaman dan 2) penggunaan rasio pinjaman / deposito (LDR). 
Non Performing Loan (NPL) adalah rasio keuangan yang digunakan untuk mengukur atau menampilkan tingkat kredit yang dihadapi bank dengan memberikan nomor kredit dan menginvestasikan dana bank dalam berbagai portofolio. Kuncoro (2002), risiko kredit / risiko gagal bayar dapat timbul karena pelanggan tidak dapat atau tidak dapat membayar kembali jumlah pinjaman yang diterima dari bank dengan bunga disesuaikan sesuai dengan jangka waktu yang diharapkan. Indra dan Julian (2015) menemukan bahwa kredit macet memiliki efek buruk yang signifikan terhadap pengembalian aset (ROA). Pendapat berbeda dari penelitian Pinasti (2018) dalam hal NPL memiliki dampak, tetapi tidak ada pengembalian besar atas aset (ROA), dan semakin banyak kredit macet semakin besar ukuran bisnis bank dan semakin rendah sisi pengamat, semakin tinggi NPL. Dan kredit risiko meningkat (Mawardi, 2005, Maria 2015). Loan to Deposit Ratio (LDR) juga disebut sebagai rasio kredit terhadap total uang pihak ketiga yang digunakan untuk mengukur uang pihak ketiga yang disediakan atau dibayar sebagai kredit. Distribusi kredit adalah kegiatan utama bank, karena sumber utama pendapatan bank berasal dari kegiatan ini (Maria, 2015).

Indarwati dan Anan (2014) menemukan bahwa rasio pinjaman terhadap deposito (LDR) memiliki efek positif yang signifikan terhadap pengembalian aset (ROA). Pendapat berbeda dari Pinasti (2018) dalam hal rasio pinjaman terhadap deposito (LDR) memiliki efek yang merugikan terhadap pengembalian aset (ROA) dan tidak signifikan, jadi di sini adalah titik yang jelas di mana pinjaman mempengaruhi rasio simpanan (LDR) Perhatikan bahwa tidak ada kejelasan tentang pengembalian aset (ROA). Semakin tinggi rasio deposito-ke-deposito (LDR), semakin tinggi laba bank (dengan asumsi bahwa bank dapat mengalihkan kredit secara efektif). Ukuran rasio pinjaman terhadap deposito (LDR) bank dapat memengaruhi kinerja bank, karena peningkatan laba bank dapat meningkatkan kinerja bank. Kemampuan bank untuk menghasilkan keuntungan dari LDR dan NPL dipengaruhi (Nusantara, 2009 dalam Masdupi, 2014).

Fenomena yang muncul dalam penelitian ini adalah kompensasi eksekutif untuk kinerja keuangan perusahaan, yang telah dibahas di antara para sarjana dengan konsensus tentang sifat hubungan antara kompensasi dan kinerja. Studi ini divalidasi dengan mencari detail dan dilakukan untuk memahami dengan jelas hubungan antara variabel (Nola dan Youssef Mohamed, 2013). Studi sebelumnya telah menunjukkan bahwa hubungan antara kompensasi eksekutif dan pengembalian pengeluaran adalah rasio yang lemah, sehingga penelitian ini umumnya berusaha untuk secara jelas menentukan tingkat dan sifat hubungan antara variabel. Tujuan dari penelitian ini adalah untuk memahami pengaruh kompensasi eksekutif, pinjaman tidak teratur, dan rasio pinjaman terhadap deposito (LDR) pada kinerja keuangan perusahaan perbankan. Berdasarkan latar belakang diatas maka peneliti tertarik untuk melakukan penelitian mengenai "Pengaruh Kompensasi Eksekutif Dan Efisiensi Operasional Terhadap Kinerja Keuangan Pada Sektor Perbankan Yang Terdaftar Di Bursa Efek Indonesia Tahun 2016-2018”.

\section{TELAAH LITERATUR DAN PENGEMBANGAN HIPOTESIS \\ Teori Keagenan (Agency Theory)}

Teori agensi menyediakan wawasan analitis yang dapat menilai efek dan hubungan antara agen dan manajer atau antara manajer dan manajer. Jesen dan Meckling (1996) mengungkapkan bahwa teori agensi adalah kontrak kerja antara manajer dan agen. Teori ini memberikan wawasan analitis yang dapat menilai dampak hubungan antara agen dan prinsipal atau prinsipal. Jensen dan Milling (1976) menggambarkan teori agensi sebagai kontrak kerja antara manajer dan pekerja. Dalam perjanjian ini, satu atau lebih manajer (pemilik) mendelegasikan wewenang pengambilan keputusan kepada agen (manajer). Manajer harus memberikan informasi tentang 
kondisi perusahaan kepada pemilik atau pemilik, seperti pengungkapan informasi akuntansi dalam bentuk laporan tahunan, untuk menilai kinerja manajer (Al-Masry dan Martany, 2012).

Teori agensi menggambarkan hubungan antara dua pihak dengan berbagai kepentingan terkait administrasi bisnis. Masing-masing mungkin memiliki preferensi yang berbeda. Pemilik dapat mengharapkan pengembalian investasi yang menarik, tetapi pemilik perusahaan dapat mengharapkan fleksibilitas dalam mengelola perusahaan. Pemilik berharap bahwa eksekutif perusahaan tidak akan menggunakan proyek berisiko tinggi agar tidak mengurangi potensi keuntungan, sementara eksekutif bisnis akan mempekerjakan proyek berisiko tinggi untuk mendapatkan hadiah untuk sukses. Kami berharap untuk mengadopsi.

\section{Kinerja Keuangan}

Kinerja keuangan adalah hasil dari kegiatan perusahaan yang mengelola semua sumber daya untuk mencapai efisiensi dan efektivitas di sektor keuangan selama periode waktu tertentu. IAI (2007), Kinerja Keuangan adalah kemampuan perusahaan untuk mengelola dan mengendalikan sumber daya. Pemahaman lain tentang kinerja keuangan, dari pemahaman saya (2006: 63), adalah deskripsi tingkat implementasi kegiatan untuk mencapai tujuan, sasaran, misi dan visi rencana. Menganalisis kinerja keuangan perusahaan biasanya melibatkan peninjauan data laporan keuangan, melakukan perhitungan, membandingkan hasil akun yang diperoleh, menafsirkan berbagai masalah yang ditemukan, mencari solusi untuk masalah, dan menyediakan solusi tersebut. Termasuk lima tahapan yang harus dilakukan. (Solusi) Berbagai masalah ditemukan (Fahmy, 2011).

Menurut evaluasi kinerja bisnis, evaluasi kinerja memainkan peran yang sangat penting dalam memastikan tingkat keberhasilan bisnis suatu entitas dan memberikan dasar untuk perencanaan strategis dan operasional di masa depan. Pemerintah tertarik pada informasi tentang kinerja perusahaan sebagai dasar untuk menentukan beban pajak, menetapkan berbagai kebijakan peraturan, dan menjaga stabilitas ekonomi nasional (Fahmy, 2011). Evaluasi kinerja adalah evaluasi yang efektif dari suatu organisasi, bagian dari suatu organisasi, dan karyawan berdasarkan kriteria dan kriteria yang sebelumnya ditetapkan oleh perusahaan. Standar dan standar ini adalah dalam bentuk kebijakan administratif dalam perencanaan perusahaan. Evaluasi kinerja juga digunakan untuk membatasi tindakan yang perlu dilakukan. Menilai perilaku manusia berdasarkan peran yang dilakukan dalam perusahaan disebut penilaian kinerja.

Perusahaan mengukur dan mengevaluasi kinerja perusahaan dan mengkonfirmasi bahwa hasil yang dicapai dengan menggunakan analisis laporan keuangan telah meningkat. Data keuangan adalah sumber informasi perusahaan untuk menganalisis dan mengetahui evaluasi pekerjaan dan nilai perusahaan, dan untuk mengetahui kinerja perusahaan dalam mengelola dan mengalokasikan sumber daya perusahaan. Setiap perusahaan tergantung pada kinerjanya. Evaluasi kinerja penting bagi manajemen untuk memastikan tingkat keberhasilan bisnis dan untuk memberikan landasan bagi perencanaan dan operasi strategis di masa depan. Evaluasi kinerja, di sisi lain, penting bagi pemilik perusahaan sehingga modal yang diinvestasikan dalam perusahaan digunakan sesuai dengan tujuan perusahaan. Investor potensial dan informasi penilaian kinerja investor, informasi penilaian kinerja sangat penting dalam memutuskan untuk membeli, memelihara, atau menjual saham perusahaan. Pemerintah juga sangat penting karena evaluasi kinerja adalah dasar untuk menentukan beban pajak, menyediakan fasilitas dan kebijakan peraturan, dan menjaga stabilitas ekonomi nasional. 


\section{Return On Asset (ROA)}

Pengembalian investasi adalah kemampuan modal yang diinvestasikan dalam semua aset perusahaan untuk menghasilkan laba. Return on equity menggunakan pendapatan sebagai alat untuk mengukur penggunaan aset perusahaan secara efektif untuk laba. Semakin tinggi laba, semakin tinggi pengembalian investasi, yang menunjukkan bahwa perusahaan lebih efektif dalam menghasilkan laba menggunakan aset. Pengembalian aset dihitung berdasarkan rasio laba setelah pajak terhadap total aset. Pengembalian survei ini digunakan sebagai indikator kinerja bank. ROA menunjukkan efektivitas perusahaan dalam menghasilkan satu atau lebih keuntungan dengan meningkatkan aset perusahaan. Karena jumlah pengembalian investasi dipengaruhi oleh jumlah laba yang dihasilkan perusahaan, laba atas investasi yang lebih tinggi menunjukkan efektivitas perusahaan (Puspitasari, 2015).

Informasi kinerja sangat berguna bagi pengguna data keuangan. Sekelompok investor, kreditor dan masyarakat ingin berinvestasi di bank untuk melihat kinerjanya. Pengembalian investasi modal berguna untuk penilaian bisnis, analisis profitabilitas, perkiraan laba, perencanaan dan manajemen. Bank dengan aset agregat yang relatif besar bekerja lebih baik. Ini karena bank memiliki keseluruhan pengembalian yang relatif tinggi sebagai akibat dari peningkatan penjualan produk. Meningkatkan total pendapatan akan meningkatkan laba perusahaan, yang akan meningkatkan kinerja keuangan perusahaan (Mawardi, 2005)

\section{Kompensasi Eksekutif}

Remunerasi adalah hadiah atau hadiah untuk pekerjaan yang dilakukan oleh departemen atau karyawan dengan imbalan jasa kerja. Kinerja dapat dinilai dan diukur secara objektif sesuai dengan keputusan perusahaan, dan jumlah kompensasi yang diterima oleh manajemen atau karyawan akan mempengaruhi kinerja karyawan yang relevan dan akan mempengaruhi kinerja Sedarmayanti (2011). Hadiah harus mengikuti sasaran dan strategi perusahaan. Berikut ini adalah beberapa tujuan kompensasi yang efektif di perusahaan.

a) Kepatuhan dengan hukum yang berlaku

b) Hemat biaya untuk perusahaan

c) SDM menerima keadilan internal, eksternal dan pribadi

d) Meningkatkan kinerja perusahaan

Kompensasi biasanya dibagi menjadi dua bagian: kompensasi langsung dan kompensasi tidak langsung. Kompensasi langsung terdiri dari upah, gaji pokok, pembayaran insentif, opsi saham dan bonus, dan kompensasi tidak langsung termasuk asuransi kesehatan atau jiwa, liburan, jaminan sosial, dana pensiun, kompensasi pekerja, dll. (Hasibuan, 2012). Cakupan langsung meliputi:

A) Gaji

Penggajian adalah layanan pembayaran yang dilakukan secara teratur sesuai dengan kebijakan perusahaan. Gaji diberikan kepada karyawan untuk pembayaran mingguan, bulanan, dan tahunan. B) Upah insentif

Upah insentif adalah penghargaan yang diberikan untuk memotivasi pekerja untuk meningkatkan kinerja mereka dan tidak tetap. Perusahaan memiliki hasil yang dirancang untuk memberikan insentif kepada karyawan yang berkinerja baik dan untuk meningkatkan dan memotivasi karyawan untuk meningkatkan kinerja perusahaan. 
C) Hadiah

Bonus adalah hadiah untuk hasil bisnis yang memenuhi tujuan dan tidak diberikan melalui prosedur normal. Hadiah berasal dari sebagian kecil dari keuntungan perusahaan. Perusahaan tidak memberikan bonus kepada karyawan, tidak harus setiap tahun. Kompensasi tidak langsung meliputi:

1. Pembayaran upah untuk tidak bekerja, seperti liburan, sakit, dan liburan.

2. Perlindungan ekonomi seperti pensiun, tunjangan hari tua dan jaminan sosial.

3. Program layanan karyawan seperti hiburan, perumahan, hibah pendidikan dan layanan lainnya.

Kompensasi eksekutif adalah kompensasi untuk eksekutif tingkat tertinggi di perusahaan. Biasanya, ada empat jenis kompensasi tingkat eksekutif: pembayaran dasar termasuk gaji dan jaminan bonus; insentif jangka pendek adalah dalam bentuk kompensasi tunai atau stok; Dalam bentuk nilai ekuitas swasta yang ditentukan untuk membeli saham; biasanya mereka adalah fasilitas seperti tunjangan eksekutif dan rencana pensiun eksekutif tambahan. Remunerasi eksekutif secara langsung mencerminkan kontribusi eksekutif dengan menekankan kinerja relatif terhadap rencana upah karyawan lainnya (Dessler, 2015).

Remunerasi membantu perusahaan memperoleh bakat dan kemampuan yang tepat untuk melakukan tugas dan tanggung jawab tertentu, imbalan membantu perusahaan menduduki posisi kepemimpinan perusahaan, dan desain insentif mempengaruhi Pertumbuhan perusahaan yang mungkin tumbuh dari program kompensasi eksekutif. Kompensasi eksekutif yang efektif juga membantu mengurangi pergantian eksekutif yang disebabkan oleh hasil operasi yang buruk karena Anda tidak puas dengan kompensasi yang Anda terima.

\section{Efisiensi Operasional}

Efisiensi operasional dicapai dengan meningkatkan output pada tingkat input yang sesuai. Hasil akhirnya adalah harga satuan yang lebih kompetitif untuk menciptakan biaya integrasi yang lebih rendah daripada pesaing Bahan (2006). Efisiensi operasional adalah ukuran kemampuan perusahaan untuk melakukan pekerjaannya. Efisiensi operasional adalah efisiensi dengan mana semua aset digunakan untuk menghasilkan penjualan sehingga biaya diminimalkan dan keuntungan maksimum tercapai. (Norsatani, 2009).

Efisiensi operasional diukur berdasarkan rasio output terhadap input. Akibatnya, efisiensi mengacu pada penggunaan sumber daya dan dana dalam bentuk investasi, teknologi, orang, dan keberhasilan perusahaan produk dalam radian (2009). Penggunaan aset perusahaan secara efektif mengurangi biaya bagi perusahaan dan memungkinkan perusahaan untuk mendapatkan tabungan dan mengumpulkan cukup uang untuk menjalankan bisnisnya. Efisiensi didefinisikan sebagai rasio input terhadap output. Pengukuran efisiensi harus dilakukan dalam hal rasio, dan rasio laba dengan biaya atau waktu adalah bentuk umum dari pengukuran ini (Ivancevish, 2006). Efisiensi operasional juga mempengaruhi kinerja keuangan bank. Efisiensi operasional menunjukkan apakah bank telah menggunakan semua faktor produksi dengan benar dan efektif.

\section{Non Performing Loan (NPL)}

Non Performing Loan (NPL) adalah rasio keuangan yang digunakan untuk menunjukkan risiko kredit yang dihadapi bank akibat pinjaman dan investasi dana bank dalam berbagai portofolio. Kredit macet adalah rasio kredit yang membandingkan jumlah kredit macet yang terdiri dari kredit diragukan rendah dan kerugian terhadap semua pinjaman yang diberikan. Naiknya nilai kredit macet berarti bahwa kualitas kredit bank semakin buruk, yang berarti bahwa tingkat risiko 
kredit bagi bank sangat tinggi. Ismail (2013) kredit macet atau kredit macet dapat diklasifikasikan ke dalam tiga kategori:

1. Kredit kurang lancar

Kredit kurang lancar merupakan kredit yang telah mengalami tunggakan dengan kriteria sebagai berikut:

a) Pengembalian pokok pinjaman dan bunganya telah mengalami penundaan pembayarannya melampaui 90 hari sampai dengan kurang dari 180 hari.

b) Pada kondisi ini hubungan debitur dan bank memburuk.

c) Informasi keuangan debitur tidak dapat diyakini oleh bank.

d)

2. Kredit diragukan

Kredit diragukan merupakan kredit yang mengalami penundaan pembayaran pokok dan/atau bunga dengan kriteria sebagai berikut:

a) Penundaan pembayaran pokok dan/atau bunga antara 180 hingga 270 hari.

b)Pada kondisi ini hubungan debitur dengan bank semakin memburuk.

c) Informasi keuangan sudah tidak dapat dipercaya.

3. Kredit macet

Kredit macet merupakan kredit yang menunggak melampaui 270 hari atau lebih.

Penanaman dana bank perlu dinilai kualitasnya dengan menentukan tingkat kolektibilitas yaitu apakah lancar, diragukan atau macet. Berdasarkan SE BI No.13/30/DPNP tanggal 16 Desember 2011 ditetapkan bahwa rasio NPL tidak boleh lebih dari 5\%. Bank harus mengetahui tingkat kolektibilitas dari kredit yang diberikan, hal ini diperlukan untuk mengetahui besarnya cadangan minimum pemghapusan aktiva produktif yang harus disediakan oleh bank untuk menutup kemungkinan kerugian yang terjadi. Bank komersial biasanya mengandalkan komponen kredit untuk memperoleh earning asset, artinya bahwa bank memperoleh pendapatan dengan mengandalkan pada bunga kredit yang dipinjamkan selain obligasi rekapitalisasi (Puspitasari, 2015).

\section{Loan to Deposit Ratio (LDR)}

Rasio likuiditas adalah rasio yang digunakan untuk mengukur kemampuan bank untuk memenuhi utang jangka pendek atau utang yang jatuh tempo. Rasio likuiditas ini adalah rasio yang sering digunakan untuk mengevaluasi kinerja bank. LDR adalah rasio dari jumlah total kredit yang diberikan oleh bank dengan jumlah yang diterima oleh Lukman Dendawijaya (2003).

Loan To Deposit Ratio (LDR) adalah rasio pinjaman yang diberikan kepada pihak ketiga dalam rupee dan mata uang asing, dan tidak termasuk kredit dari bank lain. Rasio LDR menunjukkan seberapa besar kemampuan bank untuk membayar penarikan dana yang disediakan oleh deposan dengan mengandalkan pinjaman sebagai sumber likuiditas. Rasio LDR dapat menunjukkan bagaimana mengkredit pelanggan mengimbangi kewajiban bank untuk memenuhi permintaan deposan yang ingin menarik dana yang digunakan oleh bank untuk memberikan kredit. Tingkat LDR minimum yang ditetapkan oleh Bank Indonesia adalah 78\%. Dengan kata lain, jika bank komersial tidak dapat memberikan kredit lebih tinggi dari angka ini, bank akan dianggap kurang efisien dalam memberikan kredit, tetapi jika kredit dapat diperpanjang melebihi harga yang ditentukan oleh bank, Bank Indonesia Kami percaya bahwa distribusi ini efektif. Jika distribusi jalur kredit melebihi atau melebihi ambang batas 100\%, bank dianggap terlalu agresif 
sehingga dapat meningkatkan eksposur terhadap risiko yang dihadapinya. Oleh karena itu, nomor LDR harus dipertahankan oleh bank untuk mempertahankan yang ideal dengan nomor yang telah ditetapkan.

\section{Pengaruh Kompensasi Eksekutif terhadap Return On Asset (ROA)}

Menurut Sedarmayanti (2011: 239), kompensasi adalah kegagalan fungsi atau pemberian kompensasi oleh manajemen atau karyawan yang bertindak sebagai kompensasi untuk pekerjaan. Kinerja yang disetujui ditentukan sesuai dengan tujuan yang ditetapkan oleh perusahaan. Ukuran manfaat yang dibayarkan oleh manajemen dapat meningkatkan kinerja karyawan dan meningkatkan kinerja perusahaan. Remunerasi eksekutif bertanggung jawab untuk meningkatkan kinerja perusahaan, dan manajemen bertanggung jawab untuk meningkatkan kinerja perusahaan. Kompensasi eksekutif juga merupakan salah satu cara untuk mengatasi konflik yang sering terjadi di perusahaan. Berdasarkan temuan yang ditemukan, ada hasil perbandingan kompensasi keuangan perusahaan (Komang dan I Gede, 2015).

H1: Kompensasi berpengaruh positif terhadap Return On Asset (ROA)

\section{Pengaruh Non Performing Loan (NPL) terhadap Return On Asset (ROA)}

Masdupi (2014), Dini Attar, Islahuddin, M. Shibri (2014), Indah Kostia Rene, dan Sihoda Sofyan (2013) percaya bahwa NPL memiliki dampak signifikan terhadap pengembalian aset (ROA). Sukarno dan Syaichu (2006) melaporkan bahwa NPL yang lebih tinggi menambah biaya cadangan lain ke dalam biaya cadangan, menyebabkan kerugian bagi bank, dengan kata lain, Non Performing Loan (NPL) menurunkan profitabilitas bank. Sehingga hipotesis yang dapat diambil adalah:

H2: Non Performing Loan (NPL) berpengaruh positif terhadap Return On Asset (ROA)

\section{Pengaruh Loan To Deposit Ratio (LDR) terhadap Return On Asset (ROA)}

Loan to Deposit Ratio (LDR) Penelitian sebelumnya oleh Farah Margarita, Marcelli Pengkan Zai (2013), Mario Cristiano, Barengkuan Tommy, Yvonne Saiering (2014), Mulatsih (2014), dan Vivin Indarwati (2014), Eddie Annan (2014) menemukan bahwa Loan to Deposit Ratio (LDR) adalah penelitiannya. (LDR) memiliki dampak positif yang signifikan terhadap Return on asset (ROA). Bank likuiditas menunjukkan bahwa bank likuiditas semakin memburuk, karena pembiayaan kredit juga didanai oleh dana pihak ketiga yang ditarik setiap saat. Jadi hipotesisnya bisa diambil adalah:adalah:

H3: Loan To Deposit Ratio (LDR) berpengaruh positif terhadap Return On Asset (ROA)

\section{KERANGKA KONSEPTUAL}

Untuk memudahkan memahami faktor-faktor yang mempengaruhi kinerja keuangan perbankkan maka penulis menyusun kerangka konseptual sebagai berikut:

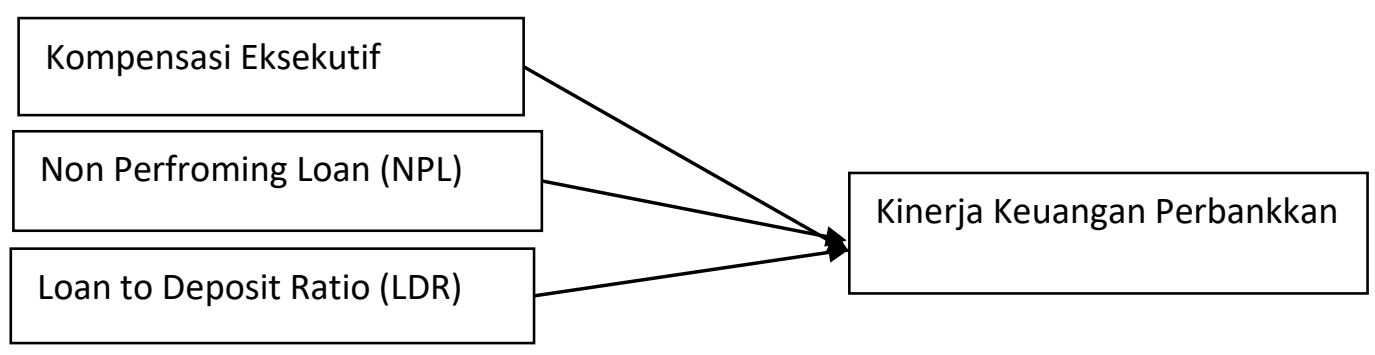




\section{METODE PENELITIAN}

\section{Jenis Penelitian}

Jenis penelitian ini tergolong penelitian kausalitas, penelitian kausalitas bertujuan untuk mengetahu bagaimani hubungan serta pengaruh variabel independen terhadap variabel dependen.

\section{Populasi dan Sampel}

Populasi adalah semua elemen yang dapat digunakan dengan membuat kesimpulan. Populasi pada penelitian ini adalah perusahaan perbankkan yang tedafatar dibursa efek Indonesia tahun 2016-2018. Pengambilan sampel dalam penelitian ini dilakukan dengan teknik purposive sampling yaitu pemilihan sampel berdasarkan kriteria tertentu.

\section{Jenis dan Teknik Pengumpulan Data}

Jenis data digunakan sekunder. Teknik pengumpulan data menggunakan teknik dokumentasi dengan melihat laporan tahunan yang diterbitkan oleh perusahaan perbankkan dari tahun 20162018. Data diperoleh dari situs resmi Bursa Efek Indonesia (www.idx.co.id).

\section{HASIL DAN PEMBAHASAN}

Tabel 1. Descriptive Statistics

\begin{tabular}{lrrrrr}
\hline & N & Minimum & \multicolumn{1}{l}{ Maximum } & \multicolumn{1}{l}{ Mean } & Std. Deviation \\
\hline $\mathrm{x} 1$ & 117 & -12625.00 & 1422652.00 & 124949.5641 & 233499.48448 \\
\hline $\mathrm{x} 2$ & 117 & 1.00 & 992.00 & 183.5641 & 155.97836 \\
\hline $\mathrm{x} 3$ & 117 & 771.00 & 14526.00 & 7365.9060 & 2885.96276 \\
\hline $\mathrm{Y}$ & 117 & -11.15 & 384.00 & 105.4931 & 101.55193 \\
\hline Valid N (listwise) & 117 & & & & \\
\hline
\end{tabular}

Pada tabel 1 menjelaskan variabel-variabel penelitian ini. Variabel kompensasi eksekutif memiliki rata-rata 124949.5641 dengan standar deviasi 233499.48448 kompensasi tertinggi adalah 1422652 dan terendah adalah -12625. Variabel non performing loan (NPL) memiliki ratarata 183.5641 dengan standar deviasi 155.97836 non performing loan (NPL) tertinggi adalah 992.00 dan terendah adalah 1.00. Variabel loan to deposit ratio (LDR) memiliki rata-rata 7365.9060 dengan standar deviasi 2885.96276 loan to deposit ratio (LDR) tertinggi adalah 14526.00 dan terendah adalah 771.00. Variabel return on asset (ROA) memiliki rata-rata 105.4931 dengan standar deviasi 101.55193 return on asset (ROA) tertinggi adalah 384.00 dan terendah adalah -11.15 .

Tabel 2. Uji F

\begin{tabular}{|c|c|c|c|c|c|}
\hline Model & Sum of Squares & Df & Mean Square & $\mathrm{F}$ & Sig. \\
\hline Regression & 519193.269 & 3 & 173064.423 & 28.883 & $.000^{\mathrm{b}}$ \\
\hline 1 Residual & 677090.902 & 113 & 5991.955 & & \\
\hline Total & 1196284.171 & 116 & & & \\
\hline $\begin{array}{l}\text { a. Dependent } \\
\text { b. Predictors: } \\
\text { sumber } \cdot \text { Outn }\end{array}$ & $\begin{array}{l}\text { Tariable: } \mathrm{y} \\
\text { Constant), x3, x1 }\end{array}$ & & & & \\
\hline
\end{tabular}


Berdasarkan tabel 2 diatas, dapat disimpulkan bahwa nilai sig. sebesar 0,000<0,05 dengan demikian dapat disimpulkan bahwa variabel independen berupa Kompensasi, NPL dan LDR secara bersama-sama memiliki pengaruh yang signifikan terhadap variabel dependen yaitu Kinerja Keuangan Perbankan (ROA).

Tabel 3. Uji Adjusted $\mathbf{R}^{2}$

\begin{tabular}{lccrc}
\hline Model & R & R Square & $\begin{array}{c}\text { Adjusted R } \\
\text { Square }\end{array}$ & $\begin{array}{c}\text { Std. Error of the } \\
\text { Estimate }\end{array}$ \\
\hline 1 & $.659^{\mathrm{a}}$ & .434 & .419 & 77.40772 \\
\hline a. Predictors: (Constant), x3, x1, x2 & & & \\
\hline
\end{tabular}

Berdasarkan hasil perhitungan diperoleh nilai koefisien determinasi (Adjuste R Square) sebesar 0,419. Hal ini berarti bahwa besar variasi variabel kinerja perbankan di Indonesia (ROA) yang dapat diterangkan oleh variasi variabel Kompensasi, NPL dan LDR adalah 41,9 persen sedangkan sisanya 58,1 persen dipengaruhi oleh variabel lain diluar model penelitian.

Tebel 3. Uji Regresi Berganda

\begin{tabular}{lrrrrr}
\hline \multirow{2}{*}{ Model } & \multicolumn{1}{l}{ Unstandardized Coefficients } & Standardized Coefficients & T & Sig. \\
\cline { 2 - 6 } & \multicolumn{1}{c}{$\mathrm{B}$} & Std. Error & Beta & & \\
\hline (Constant) & 21.996 & 20.258 & & 1.086 & .280 \\
\hline $\mathrm{x} 1$ & $-1.710 \mathrm{E}-005$ & .000 & -.039 & -.553 & .581 \\
\hline $\mathrm{x} 2$ & -.374 & .050 & -.575 & -7.504 & .000 \\
\hline $\mathrm{x} 3$ & .021 & .003 & .595 & 7.781 & .000 \\
\hline
\end{tabular}

a. Dependent Variable: $\mathrm{y}$

Berdasarkan tabel berikut dapat disusun persamaan regresi sebagai berikut:

$$
R O A=21,996-1,710 X 1-0,374 X 2+0,021 X 3+e
$$

Keterangan:

$\mathrm{Y}=$ Kinerja Keuangan Perusahaan Perbankkan (ROA)

a $\quad=$ Konstanta

$\mathrm{X}_{1} \quad=$ Kompensasi Eksekutif

$\mathrm{X}_{2} \quad=$ Non Performing Loan (NPL)

$\mathrm{X}_{3}=$ Loan To Deposit Ratio (LDR)

$\boldsymbol{e} \quad=$ Standar error

\section{Hipotesis 1}

Penelitian ini dapat membuktikan kompensasi eksekutif (X1) tidak memiliki pengaruh terhadap kinerja keuangan perusahaan perbankkan, dengan demikian hipotesis pertama (H1) ditolak. 


\section{Hipotesis 2}

Penelitian ini dapat membuktikan non performing loan (NPL) (X2) berpengaruh negatif signifikan terhadap kinerja keuangan perusahaan perbankkan, dengan demikian hipotesis kedua (H2) diterima.

\section{Hipotesis 3}

Penelitian ini dapat membuktikan loan to deposit ratio (LDR) (X3) berpengaruh signifikan positif terhadap kinerja keuangan perusahaan perbankkan, dengan demikian hipotesis pertama (H3) diterima.

\section{PEMBAHASAN}

Penelitian ini menunjukan bahwa variabel kompensasi eksekutif, non performing loan (NPL) dan loan to deposit ratio (LDR) secara bersama-sama berpengaruh signifikan terhadap kinerja keuangan perusahaan perbankkan (ROA), secara parsial hanya variabel Loan To Deposit Ratio (LDR) saja yang memiliki pengaruh positif dan signifikan terhadap kinerja keuangan perbankkan dengan nilai koefisiennya adalah 0,021. Non performing loan (NPL) memiliki pengaruh negatif dan signifikan terhadap kinerja keuangan perbankkan dengan nilai koefisien adalah 0,374 dan kompensasi eksekutif tidak memiliki pengaruh terhadap kinerja keuangan perbankkan dengan nilai koefisien 1.710, sedangkan menurut Gruilford (1956) hasil yang berada didalam angka 20$40 \%$ dinyatakan rendah.

\section{Pengaruh Kompensasi terhadap Return On Asset (ROA)}

Hipotesis pertama pada penelitian ini menemukan bahwa kompensasi berpengaruh positif terhadap Return On Asset (ROA). Berdasarkan hasil dari pengolahan data yang telah dilakukan, maka hipotesis pertama ditolak karena tidak signifikan, yang berarti variabel kompensasi tidak berpengaruh signifikan terhadap Return On Asset (ROA).

Faktor kompensasi adalah -1.710, yang menunjukkan bahwa kompensasi tidak berdampak pada kinerja keuangan bank. Kompensasi yang diberikan kepada eksekutif dalam penelitian ini menemukan bahwa tingkat kompensasi yang diterima oleh eksekutif tidak berpengaruh pada peningkatan kinerja perusahaan. Kompensasi yang tinggi tidak mewakili kinerja yang baik. Ini karena perusahaan besar akan membayar lebih banyak kompensasi daripada perusahaan kecil. Pemilik perusahaan harus memberikan kompensasi sesuai dengan kebijakan agensi kontraktual antara pemegang saham (pemegang saham utama) dan manajemen perusahaan (agen) sehingga manajemen bertanggung jawab untuk meningkatkan keuntungan pemilik atau pemegang saham sehingga manajemen eksekutif dapat meningkatkan kinerjanya seperti yang diharapkan. Oleh pemilik dan pemegang saham.

Studi ini konsisten dengan René M. Stulz (2010) yang menemukan bahwa kurangnya bukti pengaruh kompensasi eksekutif yang tinggi dapat meningkatkan kinerja atau menjadi lebih baik. Dapat disimpulkan bahwa hasil pengolahan data yang diperoleh dalam kompensasi eksekutif tidak berpengaruh pada pengembalian aset. Dengan demikian, berdasarkan hasil pengolahan data dan analisis kondisi eksperimental, dapat disimpulkan bahwa kompensasi tidak berpengaruh pada pengembalian aset.

\section{Pengaruh Non Performing Loan (NPL) terhadap Return On Asset (ROA)}

Hipotesis kedua dalam penelitian ini menemukan bahwa NPL berpengaruh terhadap Return On Asset (ROA). Hasil dari pengolahan data yang telah dilakukan, maka hipotesis kedua diterima 
(negatif dan signifikan) yang menunjukan bahwa variabel NPL berpengaruh negatif signifikan terhadap Return On Asset (ROA).

Nilai koefisien NPL sebesar 0,347 membuktikan bahwa pengaruh NPL sangat rendah terhadap ROA. NPL menunjukan pengaruh negatif yang berarti bahwa setiap kenaikan NPL akan menurunkan kinerja bank, karena dengan semakin tingginya kredit macet, maka pendapatan bank yang berasal dari bunga kredit akan semakin menurun, sehingga dapat menurunkan kinerja bank. Kondisi ini menuntut manajer agar melakukan analisis yang lebih baik lagi ketika pihak manajemen memutuskan untuk memberikan kredit kepada masyarakat (nasabah), sehingga dapat menimalisir terjadinya kredit bermasalah. Apabila suatu perusahaan perbankkan yang memiliki nilai NPL tinggi, maka akan memperbesar biaya baik pada biaya pencadangan aktiva produktif maupun aktiva lainnya, sehingga berpotensi menimbulkan kerugian pada bank dan dampaknya semakin menurunkan kinerja perbankkan.

Hasil penelitian ini sependapat dengan Dendawijaya (2009) yang menemukan bahwa akibat timbulnya kredit bermasalah (NPL) salah satunya adalah hilangnya suatu kesempatan untuk memperoleh income (pendapatan) dari kredit yang diberikan, sehingga mengurangi perolehan pendapatan bank yang dapat tercermin melalui ROA. Namun berbeda dengan penelitian Alkhatib dan Harsch (2012) yang menemukan bahwa risiko kredit (NPL) berpengaruh negative tetapi tidak signifikan terhadap ROA. Meskipun berbeda temuan penelitian, namun sebagian besar temuan hasil penelitian sebelumnya sesuai dengan hasil penelitian ini meningkatnya Non Performing Loan (NPL) berarti menunjukan adanya peluang kredit yang bermasalah akan meningkat, dan kondisi ini tentunya akan memberikan isyarat kurang baik bagi perbankkan.

Manajer harus mengantisipasi peningkatan ini dengan meningkatkan kualitas kredit melalui tahapan dan seleksi yang ketat terhadap pemberian kredit. Dengan demikian, berdasarkan hasil yang ditemukan dari pengolahan data dan analisis kondisi empiris dapat diperoleh kesimpulan bahwa Non Performing Loan (NPL) berpengaruh negatif terhadap ROA.

\section{Pengaruh Loan To Deposit Ratio (LDR) terhadap Return On Asset (ROA)}

Hipotesis ketiga dalam penelitian ini menemukan bahwa LDR berpengaruh positif terhadap Return On Asset (ROA). Hasil dari pengolahan data yang telah dilakukan, maka hipotesis ketiga diterima yang menunjukan bahwa variabel LDR berpengaruh positif dan signifikan terhadap Return On Asset (ROA).

Nilai koefisien LDR sebesar 0,021 membuktikan pengaruh LDR terhadap ROA sangat rendah. Kondisi ini membuktikan bahwa bank mampu untuk menyalurkan kreditnya denga baik, sehingga semakin tinggi kredit yang diberikan kepada masyarakat berarti semakin besar kemungkinan pendapatan yang akan diterima bank yang berasal dari bunga kredit. Meningkatnya rasio LDR dapat menunjukan ROA bank juga akan mengalami kenaikan. Rasio LDR yang semakin besar berarti bank mampu dalam memenuhi pembayaran kembali deposito yang telah jatuh tempo oleh nasabah. Semakin tinggi rasio LDR suatu bank, berarti bahwa ROA semakin meningkat dan juga dapat meningkatkan kinerja perbankkan.

Hasil penelitian ini sejalan dengan Mulatsih (2014), Adiatmayani dan panji sedana (2018) yang menemukan bahwa Loan To Deposit Ratio (LDR) berpengaruh positif terhadap ROA. Peningkatan penyaluran kredit harus didukung dengan kredit yang berkualitas dan disesuaikan dengan batas aman LDR Bank Indonesia. Bank perlu menyediakan likuiditas dalam jumlah yang cukup untuk beroperasi secara efisien dan dapat memenuhi kewajiban pada kreditur yang sudah jatuh tempo dan yang secara tiba-tiba melakukan penarikan. Penting bagi bank untuk 
mempunyai gambaran kondisi likuiditas dengan melakukan analisis ratio likuiditas yang didasarkan pada data likuiditas yang sudah berlalu. LDR menunjukan pengaruh positif yang berarti setiap kenaikan LDR dapat meningkatkan kinerja keuangan perbankkan, karena dengan semakin tingginya LDR berarti bank mampu untuk memenuhi pembayaran deposito yang telah jatuh tempo oleh nasabah. Dengan demikian, berdasarkan hasil yang ditemukan dari pengolahan data dan analisis kondisi empiris dapat diperoleh kesimpulan bahwa Loan to Deposit Ratio (LDR) berpengaruh positif dan signifikan terhadap ROA.

\section{KESIMPULAN DAN SARAN \\ Kesimpulan}

Penelitian ini bertujuan untuk menemukan bukti empiris pengaruh dari Kompensasi Eksekutif, Non Performing Loan (NPL), dan Loan To Deposit Ratio (LDR). Sampel dalam penelitian ini adalah perusahaan perbankan yang terdaftar di Bursa Efek Indonesia (BEI) selama tahun 2016-2018. Berdasarkan hasil pengujian yang telah dilakukan, dapat diperoleh kesimpulan sebagai berikut:

1. Kompensasi eksekutif terbukti tidak berpengaruh terhadap Return On Asset (ROA) hal ini mengindikasikan bahwa semakin besar atau semakin kecil Kompensasi Eksekutif, maka tidak dapat mempengaruhi besar kecilnya ROA.

2. Non Performing Loan (NPL) terbukti berpengaruh negatif signifikan terhadap Return On Asset (ROA) hal ini mengindikasikan bahwa semakin besar NPL maka semakin kecil ROA yang dihasilkan begitu juga sebaliknya.

3. Loan To Deposit Ratio (LDR) terbukti berpengaruh positif signifikan terhadap Return On Asset (ROA) hal ini mengindikasikan bahwa semakin besar atau kecilnya LDR, Maka dapat Mempengaruhi besar atau kecilnya ROA.

\section{Saran}

Berdasarkan kesimpulan diatas dapat diberikan saran sebagai berikut :

1. Penelitian mendatang diharapkan agar dapat melakukan penelitian dengan menggunakan variabel-variabel lain diluar variabel ini agar memperoleh hasil yang lebih dapat menggambarkan hal-hal apa saja yang dapat berpengaruh terhadap kinerja perusahaan perbankan.

2. Penelitian ini lebih menekankan sektor perbankan dan lebih mengacu pada bank umum go public, maka penelitian selanjutnya diharapkan dapat digunakan untuk bank yang belum atau tidak go public agar dapat memperoleh hasil yang lebih luas dan yang dapat menggambarkan kondisi bank di Indonesia secara keseluruhan.

\section{DAFTAR PUSTAKA}

Achmad, Tarmizi \& Willyanto K. Kusumo. (2003). "Analisis Rasio-Rasio Keuangan sebagai Indikator dalam Memprediksi Potensi Kebangkrutan Perbankan di Indonesia”. Jurnal Media Ekonomi dan Bisnis, Vol.XV, No.1, Juni, pp.54-75.

Bank Indonesia. (2004). Peraturan Bank Indonesia No. 6/23/DPNP tentang Sistem Penilaian Tingkat Kesehatan Bank Umum.

Bank Indonesia. (2001). Surat Edaran BI, No. 3/30/DPNP, Perihal: Laporan Keuangan Publikasi Triwulanan dan Bulanan Bank Umum serta Laporan tertentu yang disampaikan kepada Bank Indonesia, Jakarta. 
Dini Attar, Islahuddin, \& M. Shabri. (2014). Pengaruh Penerapan Manajemen Risiko Terhadap Kinerja Keuangan Perbankan yang Terdaftar di Bursa Efek Indonesia. Jurnal Akuntansi Pascasarjana Universitas Syiah Kuala ISSN 2302-0164 Pages pp. 10- 20 Volume 3, No. 1, Februari 2014.

Dian Puspasari. (2015). Pengaruh Kompensasi Eksekutif Dan Efesiensi Operasional Terhadap Kinerja Keuangan Pada Sektor Perbankan Yang Terdaftar Di Bursa Efek Indonesia. Tesis.

Khasanah, Iswatin.(2017). Pengaruh Kompensasi Manajemen Eksekutif Terhadap Kinerja Keuangan Perusahaan (Pada 50 Perusahaan Best Of The Best Versi Majalah Forbes Indonesia Tahun 2013). Jurnal Akuntansi Universitas Negeri Surabaya.

Mahardian, Pandu. (2008). Analisis Pengaruh Rasio CAR, BOPO, NPL, NIM Dan LDR Terhadap Kinerja Keuangan Perbankan (Studi Kasus Perusahaan Perbankan Yang Tercatat Di Bej Periode Juni 2002 - Juni 2007). Tesis. Magister Manajemen Universitas Diponegoro, Semarang.

Margaretha, F., \& Marsheilly Pingkan Zai. (2013). Faktor-Faktor yang Mempengaruhi Kinerja Keuangan Perbankan Indonesia . Jurnal Bisnis dan Akuntansi Vol. 15, No. 2, Desember 2013, Hlm. 133-141.

Maria, A. (2015). Pengaruh CAR, BOPO, NIM, NPL, DAN LDR Terhadap ROA: Studi Kasus pada 10 Bank Terbaik di Indonesia Periode 2007-2011 . Calyptra: Jurnal Ilmiah Mahasiswa Universitas Surabaya Vol.4 No.1 (2015).

Mulatsih. (2014). Pengaruh Rasio Keuangan Terhadap Tingkat Kinerja pada Bank Pembangunan Daerah . Jurnal Etikonomi Vol. 13 No. 2 Oktober 2014.

Nulla dan Mohammed. (2013). The Effect of Return on Assets (ROA) on CEO Compensation System in TSX/S\&P and NYSE Indexes Companies. International Journal of Scientific \& Engineering Research, Volume 4, Issue 2, February 2013.

Parimana, dan Wisadha. 2015. Pengaruh Privatisasi, Kompensasi Manajemen Eksekutif, dan Ukuran Perusahaan Pada Kinerja Keuangan. Bali: Universitas Udayana.

Puspita Sari. (2014). Kompensasi Eksekutif Dan Kinerja Operasional Perbankan Indonesia. Diponegoro Journal Of Accounting Volume 03 Nomor 02 Tahun 2014, Halaman 1-7.

Rini, I. K., \& Syuhada Sufian. (2013). Analisis Pengaruh NPL, Proporsi Dewan Komisaris Independen, BOPO, CAR DAN Ukuran Perusahaan Terhadap Kinerja Keuangan (Studi Pada Bank Non Devisa di Indonesia Periode 2008-2011). Diponegoro Journal of Management Volum 2, Nomor ., Tahun 2013, Halaman 1-12.

Suardani, A. A., \& I Ketut Astawa. (2011). Analisis Rasio Likuiditas dan Capital Terhadap Kinerja Keuangan Perusahaan pada Perusahaan Perbankan di Bursa Efek Indonesia . Jurnal Bisnis dan Kewirausahaan Vol. 7 No. 2, Juli 2011.

Sudiyatno, Bambang. (2010). Analisis Pengaruh Dana Pihak Ketiga, BOPO, CAR dan LDR terhadap Kinerja Keuangan pada Sektor Perbankan yang Go Public di Bursa Efek Indonesia (BEI) Periode 2005-2008. Jurnal Dinamika Keuangan dan Perbankan Vol.2 No 2.

Sudiyatno, B., \& Asih Fatmawati. (2013). Pengaruh Risiko Kredit dan EfisiensiOperasional Terhadap Kinerja Bank (Studi Empirik pada Bank yang Terdaftar di Bursa Efek Indonesia). Jurnal Organisasi dan Manajemen, Volume 9, Nomor 1, Maret 2013, 73-86.

Sukarno, K. W., \& Muhamad Syaichu. (2006). Analisis Faktor-Faktor yang Mempengaruhi Kinerja Bank Umum di Indonesia . Jurnal Studi Managemen \& Organisasi Volume 3, Nomor 2, Juli, Tahun 2006, Halaman 46. 
Sunarto, N. (2013). Pengaruh Non Performing Loan Terhadap Return on Assets Sektor Perbankan di Indonesia . 87 Inovbiz, Volume 1, Nomor 1, Juni 2013, hlm. 87-97.

Vivin Indarwati, \& Edy Anan. (2014). Pengaruh Rasio-Rasio Keuangan Terhadap Kinerja Bank Di Indonesia (Studi Kasus pada Bank Pembangunan Daerah di Indonesia Periode 20082012). E B B A N K Vol. 5, No. 2, Desember 2014 Hal. 35 - 54.

Website : www.bi.go.id. Peraturan Bank Indonesia Nomor ; 6/10/PBI/ 2004 Tentang Sistem Penilaian Kesehatan Bank Umum.

Website : www.idx.co.id, Performance Summary of Listed Company.

Widati, L. W. (2012). Analisis Pengaruh CAMEL Terhadap Kinerja Perusahaan Perbankan yang Go Publik (Analysis The Influence Of Camel ( CAR, PPAP, DER, BOPO, LDR ) toward Performance of Banking Companies in Indonesia). Dinamika Akuntansi, Keuangan dan Perbankan, Nopember 2012,Hal: 105 - 119 Vol. 1, No. 2.

Widamunti, Yunmas. (2010). Analisis Pengaruh Kompensasi Manajemen Eksekutif Terhadap Kinerja Perusahaan dengan Kebijakan Deviden Sebagai Variabel Intervening. Surakarta: Universitas Sebelas Maret. 